\title{
DEVELOPMENT OF HISTORY VIRTUAL CLASS BY APPLYING COLLABORATIVE MODEL TO IMPROVE CRITICAL THINKING ABILITY
}

\author{
Nunuk Suryani \\ Faculty of Teacher Training and Education, Sebelas Maret University, Surakarta \\ nunuk_suryani_uns@yahoo.com
}

\begin{abstract}
The efforts to improve quality of history learning and to answer the global demand can be carried out by utilizing technology. One of them is by developing the virtual class in history learning. These research and development are intended to produce a collaborative model of history virtual class in order to improve the critical thinking ability on the history values at the students of Senior High School. The research is conducted at a Senior High School in Solo Raya in the year 2014. This research is designed to apply the development research pursuant to the opinion of Borg and Gall. The data are collected by using the techniques of observation, interview, document analysis, FGD (Focus Group Discussion) and questionnaire. The methods applied to analyze the data are the qualitative analysis using interactive model, evaluative and comparatives analyses. The finding of this research produces a conclusion that the model of history virtual class is effective to improve the critical thinking ability on the history values. The collaborative model of virtual class is effective to improve the role of history learning in stimulating the critical thinking ability of the students which in turn will be able to improve competence of the students.
\end{abstract}

Key words: History Virtual Class, Critical Thinking Ability, Collaborative Model.

\section{INTRODUCTION}

History learning has a very important function, namely to make students aware of the existence of change and development processes of community in the past. The other function is to build up the history perspective and awareness in finding, understanding and explaining the real self-value of the nation in the middle of changes in this world (Ministry of National Education, 2003). History is one of the chains to truly comprehend what happened in the
Upaya untuk meningkatkan kualitas pembelajaran sejarah dan untuk menjawab permintaan global dapat dilakukan dengan memanfaatkan teknologi. Salah satunya adalah dengan mengembangkan kelas virtual dalam sejarah pembelajaran. Penelitian dan pengembangan ini dimaksudkan untuk menghasilkan model kolaboratif sejarah kelas virtual untuk meningkatkan kemampuan berpikir kritis pada nilai-nilai sejarah di siswa SMA. Penelitian dilakukan di SMA Senior di Solo Raya pada tahun 2014. Penelitian ini dirancang untuk menerapkan penelitian pengembangan sesuai dengan pendapat Borg dan Gall. Data dikumpulkan dengan menggunakan teknik observasi, wawancara, analisis dokumen, FGD (Focus Group Discussion) dan kuesioner. Metode yang diterapkan untuk menganalisis data adalah analisis kualitatif dengan model interaktif, evaluatif dan analisis komparatif. Temuan penelitian ini menghasilkan kesimpulan bahwa model sejarah kelas virtual yang efektif untuk meningkatkan kemampuan berpikir kritis pada nilai-nilai sejarah. Model kolaboratif kelas virtual adalah efektif untuk meningkatkan peran sejarah pembelajaran dalam merangsang kemampuan berpikir kritis siswa yang pada gilirannya akan dapat meningkatkan kompetensi siswa.

Kata kunci: kelas virtual sejarah, kemampuan berpikir kritis, model kolaboratif 
past, its effect to the present time, and its impacts to the future (Suhartini, 2001).

Through the subject of history, students are expected to be able develop their chronological thinking ability and knowledge about the past that can be used to find and to establish the real self -value of the nation in the middle of the global communities having multidimensional nature. The multidimensional changes are accompanying and will accompany the changes in this millennium, demanding the mankind as the object of history to understand and to respond to various developing tendencies in order to be able to guide the students to better life in the future (Rochiati Wiriaatmadja, 2002). Through the subject of history, students are introduced to events in the past accompanying the establishment of community and the nation at present (Hasan, 2007).

The objectives of history learning are as follows: (1) To build up the awareness of students on the importance of 'time' and 'place' constituting a process from the past, present and future; (2) To train the critical mind of students to understand the historical facts as evidence of civilization of the Indonesian nation in the past; (3) To establish appreciation and respect of students to the historical traces as evidence of civilization of the Indonesian people in the past; (4) To establish the understanding of students to the establishment process of the Indonesian nation through a long history and is still in process up to this present time and in the future; (5) To establish the awareness in each student as a part of the Indonesian nation who feel proud and love the country that can be implemented in various kinds of fields of life, either nationally or internationally (Haryono, 1995).

The history learning is expected to be able to give the outlooks related to the events from various periods in the effort to build up the attitude and behavior of students. It is now the time that the history learning at school no longer presents the facts and chronology of the events only, but also needs to present the values able to be taken from certain events. It is necessary for the teachers to improve their techniques in presenting the materials of history able to attract the attention of students, among others through the best language mastery, knowledge enlargement through continuous reading habit, genuine interest and passion to the object of their study, the use of teaching aid, and always being up-to-date to the current events (Kartodihardjo, 1993). For this reason, the teachers are required to be creative in developing the teaching materials and the teaching method (Supriadi, 1994).

In Curriculum 2013, the subject of History is classified under the group of compulsory subject and at the same time the interest-based subject. History as the compulsory subject at present is labeled to be the subject of "Indonesian History". Whereas in the interest based subject, history is put under 'Social Interest' available at the same group with Economics, Sociology, and Anthropology. Observing the time allocation provided based on data at the table written by Hamid (2014), the Indonesian History (the compulsory subject) gets 2 hours per week for each level, either for Class X, XI or XII. Meanwhile for the Interest based subject, it has a little bit difference, in which Class $X$ is given 3 hours time and Class XI and Class XII are given 4 hours each per week.

Observing the addition in time allocation, such utilization shall be maximized. The addition of time allocation enables to carry out a development in method, in approach until the learning model as a step to establish a Histo- 
ry learning which is interesting, various, but remains meaningful. If seeing the learning model in Curriculum 2013, the process standard is formerly focused on exploration, elaboration, and confirmation completed with observing, questioning, processing, reasoning, presenting, concluding, and creating. Thus, the learning process not only occurs in the classroom, but also at the school environment and at the community. Under such condition, teachers are not the only source of learning, and the attitude is not taught verbally but through examples and good conducts of the teachers and their colleagues. This indicates that the learning model applied in Curriculum 2013 is a combination of the four models applicable at the formulated Curriculum 2013.

Mudhofir in Deni Darmawan and Permasih (2009) stated that there were four patterns of learning, namely: First, the learning pattern without using any teaching aid / teaching material in the form of visual aid. Second, the learning pattern using teaching aid / visual aid. Third, the learning pattern already applied the media. And fourth, the media pattern with students or the longdistance learning pattern using the media or prepared learning materials. Based on the aforesaid learning patterns, it is clear that learning is not merely teaching (as the first pattern), because a successful learning must give many treatments to the students. The role of teachers in learning is not just as a teacher (informer), but teachers must have multi-functions in learning. And in order to get the learning pattern applied able to be various, the learning materials have to be prepared variously, too.

The success of history learning is still under a question up to this present time. This is due to the fact that the phenomena on the existence of the nation and the state of Indonesia among young genera- tion is getting more and more doubted. Based on such reality, it means that there is something to be corrected and improved in the implementation of history learning (Alfian, 2007). Quality of learning process is influenced by the external and internal factors. Such factors cover teachers, materials, interaction patterns, media and technology, learning situation and system. There are still some teachers not mastering the materials to be presented and in evaluating their students, they demand the answers precisely the same as they explain. In other words, students are not given the opportunity to think critically and creatively. Teachers also have the limitation in accessing new information enabling them to know the latest development in their fields (state of art) and possibility of further development already been achieved at present (frontier of knowledge). Meanwhile, the learning materials in the view of students are deemed to be too theoretical, not optimally utilizing the various media (Anggara, 2007).

One of the learning models offered is the e-learning innovated model (virtual class). E-learning or electronic learning nowadays is more well-known as one of the ways to overcome the educational problems, either in advanced countries or in developing countries (Ministry of National Education, 2003). Many people use different terms for ' $e$ learning', but in principle the e-learning is a learning using the learning aid of the electronic service. E-learning is certainly a learning technology relatively new in Indonesia. To simplify this term, the electronic learning is shortened into ' $e$ -learning'. On its implementation, the elearning applies the services of audio, video or computer soft wares or a combination of the three of them. Through the e-learning, scenario of teaching \& learning needs to be prepared thorough- 
ly in a learning curriculum really designed under the internet basis. Implementing the internet-based learning does not merely mean to put the learning materials into the web. Apart from the learning materials, the learning scenario needs to be well prepared in order to invite the involvement of students actively and constructively in their learning process (Suryani,2009; 2010a; 2011a).

E-learning or virtual class is a teaching and learning applying the electronic network (LAN, WAN, or internet) to convey the content of learning, interaction, or guidance (Koran, 2002, Rosenberg, 2001). Others interpret elearning as a form of long-distance education conducted through internet media (Udan and Weggen, 2000). Whereas Dong in Kamarga (2002) defined elearning as an asynchronous learning activity through the computer electronic equipment obtaining the learning materials in conformity with its need. Or, the e-learning is defined as follows: " $E$ learning is a generic term for all technologically supported learning using an array of teaching and learning tools as phone bridging, audio and videotapes, teleconferencing, satellite transmissions, and the more recognized web-based training or computer aided instruction also commonly referred to as 'Online Courses' (Soekartawi, Haryono and Libero, 2002).

The paradigm e- learning is integrate several systems, such as : First, the paradigm of virtual teacher resources, which is able to overcome the limited amount of qualified teachers, so that the students need not intensively require support of teachers, due to the role of virtual teacher, and the major part has been taken over by the said learning system. Second, virtual school system, able to open opportunity to carry out the programs of basic education, intermediate and high education not requiring the space and time. Superiority of this paradigm is that the accommodating capacity for students is unlimited. Students are able to do the learning activity any time, any where, and from any place. Third, the paradigm of cyber educational resources system, or dot com learning resources system. It supports the two paradigms stated above, in assisting the access to electronic articles or journals available freely and free of charge in internet.

The use of e-learning cannot be separated from the role of internet. According to William (1999), "Internet is a large collection of computers in networks that are tied together so that many users can share their vast resources." The larger application of internet for educational purposes particularly in the advanced countries is a fact indicating that through this media, it is really possible to carry out the teaching-learning process more effectively. This occurs due to the sufficiently specific nature and characteristic of Internet. It is expected that it can be used as learning media as the other media already been previously used, such as radio, television, Interactive CD-ROM and the like.

The roles of teachers, especially the history teacher in a learning process integrating the ICT (Information and Communication Technology) are expected to be able to be facilitator, collaborator, mentor, trainer, director and learning mates and able to give option and big responsibility to students to experience the learning event. Meanwhile, the roles of students in a learning process integrating the ICT (Information and Communication Technology) enable students to be active participants, produce and share the knowledge / skills and participate as much as possible as commonly done by the experts, study individually and collaboratively with other students. 
Starting from one of the objectives of history learning, namely training the critical mind of students to understand the historical facts properly based on the scientific approach and scientific methodology, the integration of ICT into the learning should be combined with the learning model which is able to stimulate the critical thinking ability on students. To think critically is to think correctly in the scheme of knowing relevantly and reliably about the world. To think critically is to think reasonably, reflexively, accountably; the thinking ability being focused on decision making to the thing being believed or the thing obliged to be done. To think critically is to think to convey suitable questions, to collect relevant information, to put chronology of information efficiently and creatively, to reason logically until obtaining a reliable and trusted conclusion (Beyer, 1985, Perkin, 1992).

In order to achieve the aforesaid objective, the teachers in a learning process not only give knowledge to students. The students must build up their own knowledge by empowering their brains to think (Slavin, 1997). Teachers can help this process by means of learning, designing information to be more meaningful and more relevant for the students' needs. This can be conducted by giving opportunity to students to find or to apply their own ideas themselves, and also to ask them to realize and to consciously use their own strategies to learn. According to Nur (1999), the teachers had better only give 'ladder' which is able to help students reach higher level of comprehension, but it shall be undertaken that the students themselves step on the said ladder. One of the ways is by using the collaborative model. (Suryani, 2010b)

Collaborative Learning refers to environment and methodology of students activities in performing their general tasks, in which each individual mutually depends on and being responsible for each other. This also includes the face-to -face conversation and discussion using computer (online forum, chat rooms, etc) (Chiu, 2008; Suryani, 2011a.). The method to examine the collaborative learning process covers the 'conversation analysis' and 'statistic discourse analysis' (Chiu and Khoo, 2005).

This collaborative learning in the opinion of Vygotsky (1978) had strong roots that there was a social nature attached to the learning, reflected through his theory on proximal development zone. Frequently, the collaborative learning is used as generic term for various approaches in education, covering the joint intellectual effort by students or by students and teachers. Thus, the collaborative learning generally takes place when a group of students work together to look for the understanding, meaning, or solution to make an artifact or their product of learning. Further, the collaborative learning changing the traditional relation between students-teacher in the classroom, produces a controversy whether this paradigm is more useful collaboratively rather than harmful. The learning activity can comprise of collaborative learning, group project, problem solving together, debate, team study, and other activities.

Such approach is closely related to the 'cooperative learning' (Ibrahim and Nur, 2000; Oakley, 2004). Based on the said description, the development of history virtual class under the collaborative model is expected to be able to improve the critical thinking ability of students upon the history values.

\section{RESEARCH METHOD}

This is a development research. The development procedures adopt the 
model of learning design by Dick and Carey (2005) consisting of 9 (nine) steps, namely: (1) Identifying general objectives of learning; (2) Performing the learning analysis; (3) Identifying the characteristics and initial ability; (4) Formulating the special objectives of learning; (5) Developing a test based on standard; (6) Developing the learning strategy; (7) Developing and selecting learning materials; (8) Designing and implementing formative evaluation; (9) Revising the learning. The development procedure of this research refers to the procedure made by Borg and Gall (2007) able to be modified as follows:
The subjects of the previous study are students and teachers of Government Senior High School (SMA Negeri) in Surakarta selected by using the purposive sampling technique. The other subjects of research are the educational experts and the learning developers. The data are collected in this research by using the methods of questionnaire, interview, observation, and document analysis. The subjects of research for model testing are students and teachers of Private Senior High School in Solo Raya. Samples are selected by using the technique of stratified multistage cluster random sampling and the data are ana-

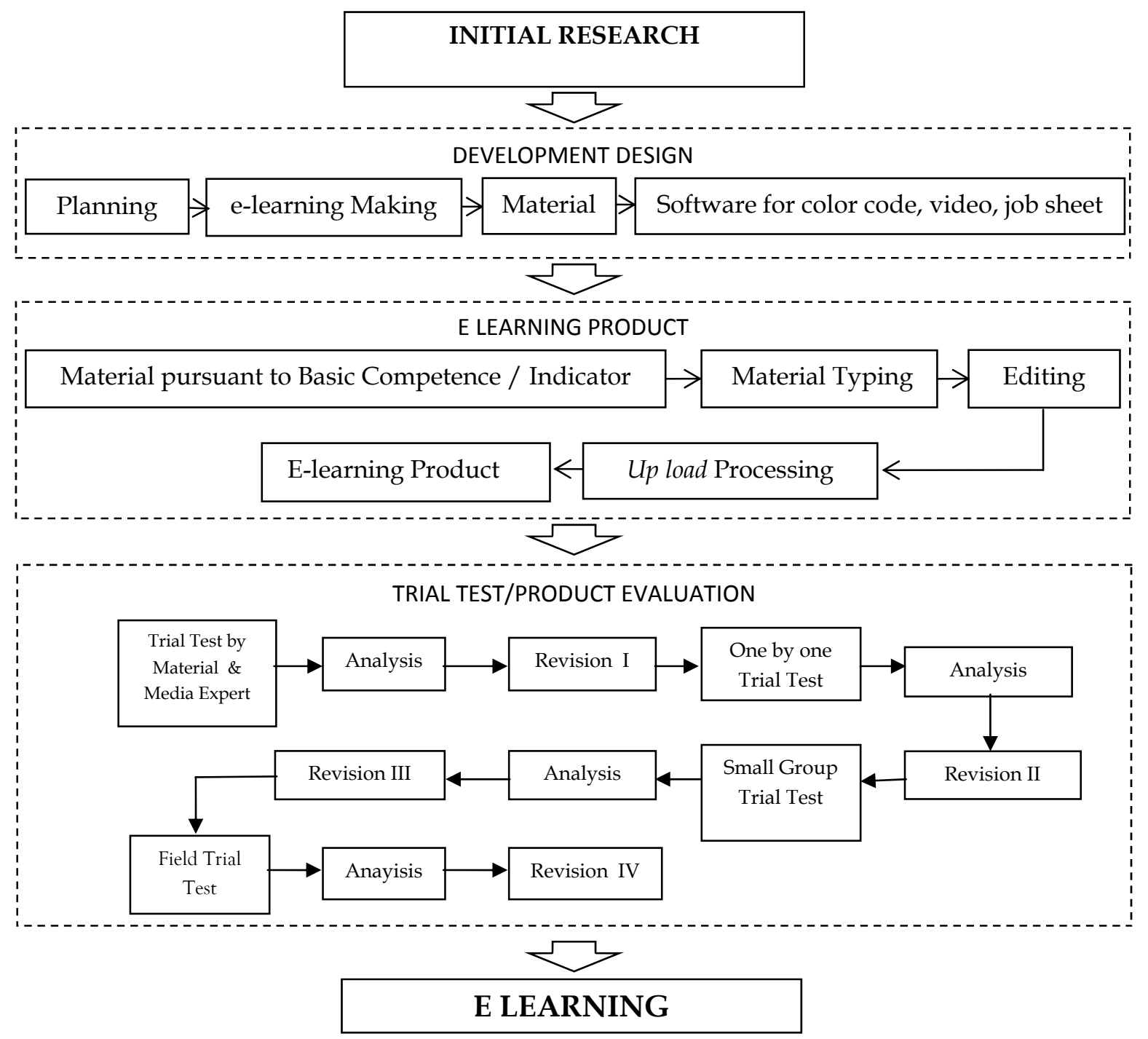

Figure-1. Procedure of E-learning Development, adopted from Borg and Gall (2007). 
lyzed by using the t-test.

\section{RESULT AND DISCUSSION}

\section{Pre-Survey Outputs: Implementation of Electronic Learning (e-learning) in Senior High School in Surakarta.}

Based on outputs of research as stated above, the writer conveys the theories obtained from the finding in this research, among others are as follows: The e-learning is carried out efficiently and effectively if it is applied in combination, namely the e-learning and conventional learning. This can settle the problems encountered by students if they do not understand a material. Teachers are demanded always to accompany the students, although only serve as facilitators. It can be stated that e-learning serves as complement for conventional learning. Both of them mutually complete each other's and each of them is unable to stand by itself.

Various efforts in the scheme of e-learning development can be carried out following the development of ICT (information and Communication Technology) available. This occurs, because sometimes the ICT facilities are not completed at the same time. And so are the prototypes of the learning materials and the instructional design to be used are continuously developed and evaluated, regardless to the support of the institutions in evaluating the said development.

Utilization of e-learning cannot be separated from the services of internet and intranet. Due to the fact that the learning technique available at the internet are so complete, this will influence the teacher's tasks at the learning process. In the past, the teaching - learning process was dominated by the role of the teacher, therefore it is also called as
"Era of Teacher". Nowadays, the teaching-learning process is more dominated by the role of teacher and book ("Era of Teacher and Book") and in the future, teaching-learning process will be dominated by the roles of teacher, book and technology ("Era of Teacher, Book and Technology").

The source of study for e-learning can be in the form of static and dynamic sources. The static source, namely the source of study not undergoing any changes inside, such as the materials in books. The dynamic source, namely the source of study undergoing the changes any time in line with the new era development. For example, the article in website of computer science of .com, every time changes adjusting to the available development of technology. This makes the learners always get the latest science / information every time.

Perception of teacher or students on the implementation of e-learning as the supporting tool for the conventional learning system is not only a process in computer installation, and network, but also requires the readiness of all the related parties covering the policy makers, teachers and students. On its development, a balanced and simultaneous attention must be given, so that the $e$ learning can be applied as optimally as possible.

The existence of the said e-learning facilities is really very helpful for students in learning, because the freedom to be able to download the materials is not limited and it can also be accessed by persons a part from the Network Computer Engineering Department. This elearning is very good in the matter of fulfilling the needs for materials, however in order to be able to study independently by using this e-learning system really takes time and good handling procedures.

There are many constraints en- 
countered in implementing the e-learning at the government senior high school in Surakarta related to the input, process, output or management. One of the prominent constraints and has to be overcome immediately is the matter of up-dating the e-learning system, commencing from the appearance, news, forum, material, and other contents supporting the e-learning system. The weak point of management in controlling the survival of the system is that there is no clear rule / regulation, so that the users, in this case teachers and students, do not pay much attention to the obligations they are supposed to do.

The other constraint is related to the supporting equipment not yet meeting the requirement and not yet sufficient. In order to obtain the maximum output of the system pursuant to the characteristics of the e-learning itself, it is absolutely necessary always to utilize the service of technology and superiority of computer as the consequence of applying CAI (Computer Assistance Instruction) and CMI (Computer Managed Instruction).

One of the standard indicators whether the e-learning is successful or not, is based on the update of all the things available at the e-learning, starting from the appearance, news, forum, materials, and other contents supporting the e-learning system itself. The demand for updating is compulsory for the $e$ learning management, because the users later on will evaluate the aforesaid system.

Regulation is absolutely applied for the existence of the e-learning system, either the regulation for management, administrator, teachers or students. This is for the survival of good system and the continuous control for quality of the said e-learning system.

The qualified and sufficient supporting equipment shall be absolutely fulfilled in order to get the maximum outputs of the system in conformity with the characteristics of the e-learning itself which always utilizes the service of technology and superiority of computer as the consequence of applying CAI (Computer Assistance Instruction) and CMI (Computer Managed Instruction).

Knowledge and skill in the fields of development and management of electronic learning activities become the most determinant factor apart from procurement of computer and internet access facilities. Finally, in the implementation of $e$-learning as the supporting tool for the conventional learning system, all the related parties, in this case, the policy makers, teachers and students must feel ready for implementation of elearning. In addition, all facilities and equipment required must be provided previously, so that the application of $e$ learning can run smoothly. On its application, it may not be executed halfheartedly; it must be deeply thought over for its development in the future.

\section{Outputs of Model Development}

Based on outputs of the initial study and analysis on requirements, a model of history virtual class is developed through a collaborative model. Having the media products been completed, then a test is conducted, either internally or externally. The initial drafts are consulted with the material experts in order to get the inputs which are then applied to be the basis to revise the said initial drafts. Further, it is consulted with the media experts in order to overcome the surplus and the shortage of the said basic concept. After consultation, a revision can be made. Then, it is continued with a trial test to the students designed for one to one evaluation, small group evaluation and field evaluation. The 


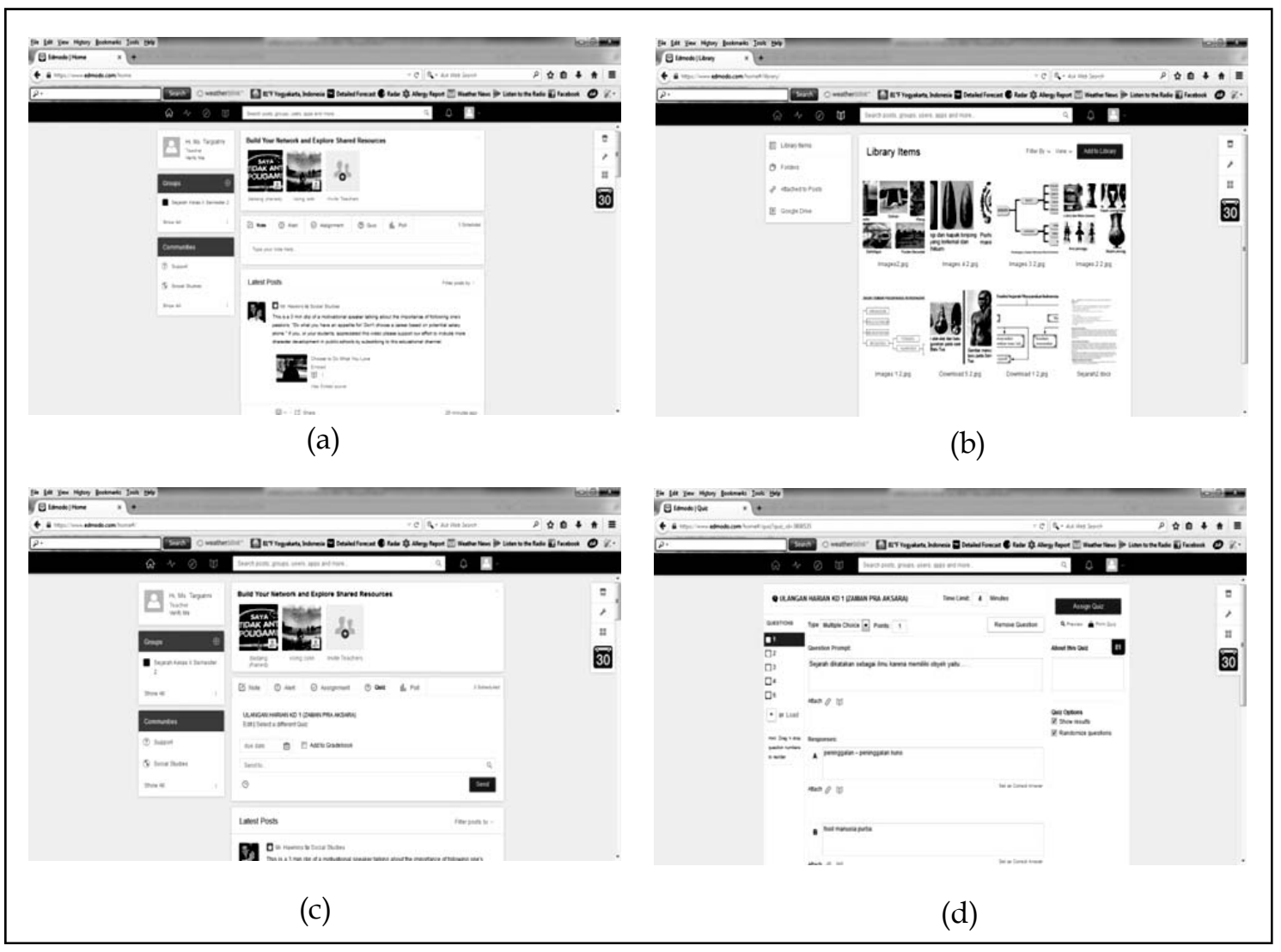

Notes:

(a) Display Home E-learning with Edmodo

(b) Examples of materials that are stored in the "library"

(c) \& (d) Examples of examination

Figure 2. Display of Edmodo

following is the product of history virtual class development at Class- $X$ of Senior High School SMA Batik-I, Surakarta, using the Edmodo.

Virtual Class is a form of information technology application in the field of education. It constitutes a change from the conventional teachinglearning process to be the digital form. The learning process of virtual class can run well if it is supported by utilization of Information Technology as the supporting tool.

The role of teachers in learning process integrating the information technology is expected to be the facilitator (provider), collaborator, mentor, trainer, director, and learning mate and able to give options and big responsibility to students to experience the real learning event (Seamolec, 2013).

Meanwhile, the role of the students themselves at the learning process integrating this information technology enables students to be active participants, producing and sharing the knowledge/skills and having participation as many as possible just like the experts in their domains, autodidact learning and collaborate with other students (Seamolec, 2013). LMS (Learning Management System) applied at the virtual class are various, starting from Moodle, Claroline, Atutor, eFront and many others. Each has its own superiority and shortage. Application of such LMS requires not small amount of infrastructure as well as the sustainable maintenance 
(Subagya, 2007). Edmodo is the answer to the aforesaid shortage.

Edmodo is a social network which can be accessed anywhere as long as internet is available. Its application is free of charge, its interface looks like Facebook (being familiar with the child world at present), its system support is good and is available in many languages, among others: English, Spain, Portuguese, Dutch, Greek, and French. The superiority of Edmodo, among others are: providing easy and safe facilities in developing the class pursuant to the intention, giving opportunity for establishment of learning pursuant to characteristics of the students who are individually different, and providing the means of communication for teachers, students and parents/guardians of the students personally. The other superiority is that Edmodo will make easy for teachers, students and parents in sharing the ideas, sharing the files, homework assignment, evaluation, quiz/test, polling, discussion, the task reminding, etc. (Seamolec, 2013).

Facilities to be obtained by a teacher in Edmodo among others are as follows: Teacher can design the online class as he likes; each class has its own unique class code (each class may be made different), controlling any one who may join, giving comment/ message to the class, to individual specifically/individually, giving assignment, responding and evaluating the worked-out tasks, making interactive quiz/test, performing the polling, establishing small groups, making personal communication, collaborating with other teachers. Edmodo is proven successful in increasing the interest and achievement of students. (Basori, 2013; Singgih Prasetiono, 2014).

Edmodo is the answer for a virtual comfortable and safe classroom because: (1) Students can carry out interaction under the monitoring of their teacher (free from cybercrime and cyber bullying); (2) Teacher can lock a student, so that he can only read and unable to comment to the whole content in "the classroom", but he is still able to communicate directly with his teacher; (3) No outsider able to enter and see the virtual class made by a teacher without having a special code from the teacher concerned; (4) Teacher can start giving questions, putting a photo or a video, presenting the learning material, in which all of them are free to be downloaded by students and to be given their comments; (5) Students can come back anytime to repeat the material given by their teacher, even the homework can be given through edmodo; (6) Students can also collect their homework through edmodo, just by uploading. Edmodo can be combined with other websites, such as 'wall wisher', 'glogster', and the like; (7) A teacher can put a score on the work of a student as a reference for the student; (8) A virtual class can be made by a teacher unlimitedly, the teacher can put a learning material to be used in a certain intake or to be used in the following academic year; (9) Students can cooperate with the others in a small group established by their teacher; (10) When working out a project together, they can put all documents required on its execution; (11) Edmodo enables a teacher to put a learning material very useful for students who are absent or unable to be present face-to-face meeting; (12) A silent student can freely talk and give opinion without being afraid to be embarrassed, while the active type student can do posting for the questions any time as long as he / she is connected to internet; (12) A teacher can teach the procedures / manners applicable in virtual world, such as the way to give comment and a series of ethics in virtual world that need to be known by stu- 
Table 1 Average large group trial data (field)

\begin{tabular}{llll}
\hline No & Indicator & Score & Category \\
\hline 1 & Aspect of media guide & 4,0 & Excellent \\
2 & Aspect of Media objective & 3,7 & Excellent \\
3 & Aspect of media description & 3,8 & Excellent \\
4 & Aspect of media display & 4,0 & Excellent \\
\multicolumn{2}{l}{ Average score of display aspect $=3,9$. Including the category of "good" } \\
\hline
\end{tabular}

dents (Seamolec, 2013).

Having completing the design for model of history virtual class for Class$\mathrm{X}$, the next step is to perform the material / content test by the material experts. The material expert selected is Sasmito, SPd, MPd. The testing indicators cover the aspects of media guidance, program objective, material description, and the program appearance. The total average value of trial test as a whole by the material / content expert is 4.5. Under a five-scaled table, the above score is classified as being "Excellent". This means that the preciseness of history virtual class development for Class- $\mathrm{X}$ is rated " $\mathrm{A}$ " by the material/content experts.

The Development Product Trial Test to the learning media experts constitutes the data related preciseness of learning media applied. The media experts selected are Prof. Dr. Mullyoto, MPd and Prof. Dr. Anitah, MPd. The evaluated aspects covers media guidance, program objective, material description, program appearance and the aspects of usage and endurance. The total average value of the evaluation outputs as a whole is 4.45. Under a five-scaled table, the above score is classified as being "Excellent".

'One-to-One Trial Test' is conducted to 5 (five) students. Output of this "One-to-One Test" is described in the form of Response Table stating that the score of each item and data of the average score of 'one-to-one trial test' is 4.2.

Further, Small Group Trial Test is carried out to 10 (ten) students. Output of this trial test of the small group is described in the form of the Response Table containing the scores of each item and data of average score. The average score of the 4 aspects is 4.15 .

Big Group (Field) Trial Test is based on the inputs from a review by the material / content expert, media expert, one-to-one trial test and a small group trial test. The next step is to perform Big Group Trial Test to 26 (twenty six) students.

The total average as a whole is 3.9. Under a five-scaled table, the said score is put in "Good" category. This means that the aspect of media learning for model development of history virtual class in Class- $X$ is rated " $B$ " by students.

\section{Output of Model Effectiveness Test}

In order to prove the effectiveness in utilization of virtual class products developed to improve the learning achievement of students, a t-test needs to be carried out. This $t$-test applies 2 independent (free) samples applied to test the average similarity of 2 independent populations. Those two populations are two sample groups each of which is treated as 'experimental group' (known as 'the virtual class learning model') and 'controlling group' (known as 'conventional learning') (Budiyono, 2009). 
From the output of $t$-test, it is obtained: $\mathrm{F}$ progression $=5.11>1.96=\mathrm{F}$ table, because $\mathrm{F}$ progression $>\mathrm{F}$ table, $\mathrm{H}_{\mathrm{o}}$ is rejected. This means that both groups do not have the same learning achievement. Due to the fact that the average learning achievement of the group applying the virtual class model being developed = $76.67>$ average learning achievement of the group using the conventional model $=60.63$, then it can be concluded from the output of aforesaid average score that the group applying the virtual class model has better learning achievement than the group applying the conventional model.

This development proves that the virtual class is effective to improve the critical thinking ability and the student's competence to the value of history. Reddy (2002) is in the opinion that $E$ learning can become a partner with the conventional learning in class. E-learning can even become a great complement to the learning model in class or as powerful tool for enrichment program. Although acknowledged that independent learning is the basic thrust for ELearning activities, the type of this learning activity still requires a sufficient interaction as an effort to maintain the learning quality. Learning by utilizing the virtual class (cyber class) constitutes an effort to motivate learning carried out any time and anywhere. Learning at the virtual class does not substitute the face-to-face learning conducted in class together with the teacher, but by utilizing the virtual class the teacher obtains the addition or enrichment in materials that will complete the conventional learning. Under such learning model, the teacher is motivated to be more active and creative. Being active and creative in the sense that in virtual class the teacher is expected to search, read, and understand the materials from various digital learning sources, besides to conclude, create, and share, either for the knowledge that he has obtained or the master piece that he has made to his friends. He is also expected to make discussion and cooperation in group virtually (Seamolec, 2014).

E-learning creates an open learning environment (Manninen \& Pesonen, 1997). E-learning with edmodo is proven to be successful to bring students to be more critical in understanding the historical values. Edmodo offers a unique opportunity to be connected to students and to help students create the norms and reflect how the different online actions will be interpreted. Edmodo offers to the teacher an opportunity to start a dialogue with students critically about the usage of social network and the ethics in using the media and online format. The superiority of Edmodo is that it has a format just like a Facebook. Facebook is a website of social network made by Marc Zuckerberg which has already been well-known in Indonesia. Facebook has been used almost by all communities when they access the internet. Just like Facebook, Edmodo is a website of social network for teachers and students which can help teachers and students in education.

Edmodo is an attractive application for teachers and students with the social elements like the Facebook, but actually there is a bigger added value in this educational application based on the social network. Edmodo (designed by an educator) which is also based on cloud collaboration constituting an application which is sufficiently safe to be used by teachers and students. A teacher, school, sub-district, regency can easily manage a system providing the best features and practically abolishing the worry to the activities usually conducted by students with the internet, particularly the Facebook. Under this platform, it will be much easier for teachers 
to monitor the students' interaction. No one can enter into the edmodo room without invitation, and students cannot use it to contact a stranger as occurs in Facebook. The teacher can easily know if there is any intruder/stranger registered in class managed by Edmodo. Edmodo is very comprehensive as a course management system just like Moodle. The difference is that its access is faster and easier to use it by applying some features whose function is the same just like a course management system.

Edmodo just like the other learning media can become just only an online platform to motivate the learning, or able to become a more creative means to involve students in collaborative learning. Edmodo is not the answer for every class but the most important thing is that this platform gives important aspect from a positive learning environment. This platform also gives students a path / route to interact with their friends and their teachers in an academic atmosphere. Further, the use of this platform can teach students on how to behave online and to be responsible in arranging their learning activities under a guaranteed security system. Essentially, this platform is easy to learn and easy to use for teachers who consider themselves available outside the basis of technological knowledge developed at present. Edmodo provides an environment in which teaching and learning can produce gaiety among students, students become more independent without neglecting the standard measuring the success of students. It is unavoidable that student will like the learning through this platform, and when students feel joyful, their intension to be able to overcome the new and difficult materials will improve. Edmodo is one of the ways to build up the spirit of students to study.

\section{CONCLUSION}

Outputs of research and development already been conducted prove that the collaborative model of history virtual class can improve the critical thinking ability of students on the values of history. E-learning or a virtual class is something absolutely needed to anticipate new era development with the support of information technology. At the era of Information Technology, all of them lead to the digital era, either its mechanism or its contents. All learning materials, internally including the history subject can be developed by using the e-learning system.

The virtual class of Edmodo is proven successful and effective to improve the success of electronic learning. Edmodo applies the design look like Facebook, and provides teachers and students the secured place to make contact, to collaborate and to share the contents. The teachers can also send the scores, assignments and quiz to students. Students can present their homework and see their scores and the teacher's comments that possibly have their tasks been in posting. Teachers can also make a survey and topic posting for discussion among students. Teachers can distinguish an individualization of learning through the establishment of sub-groups in learning activities. After completing each period of learning, the teacher closes and exits from the network and creates a new one for the next learning.

Edmodo is designed to be under a collaborative basis, so that enables it to establish a critical thinking ability with the developed online cooperation. The guiding system between the online and face-to-face meeting requires students to be more critical in understanding the values of history contained at the learning materials. 


\section{ACKNOWLEDGEMENT}

I wish to extend my sincere gratitude to the "University of Sebelasmaret Surakarta" for its sponsorship to this research through the Fund of DIPA (Budget Implementation Form) of PNBP (Non-Tax State Revenue) with the Contract No. 5401/UN27.11/PN/2014.

\section{REFERENCES}

Alfian, Magdalia. 2007. 'Pendidikan Sejarah dan Permasalahan yang Dihadapi'. Papers. Presented in Seminar Nasional Ikatan Himpunan Mahasiswa Sejarah Se-Indonesia (IKAHIMSI). State University of Semarang, Semarang, 16 April 2007

Anggara, Boyi. 2007. 'Pembelajaran Sejarah yang Berorientasi pada Masalah- Masalah Sosial Kontemporer'. State University of Semarang, Semarang, 16 April 2007Seminar Nasional Ikatan Himpunan Mahasiswa Sejarah SeIndonesia (IKAHIMSI). State University of Semarang, Semarang, 16 April 2007

Borg, W.R, Joyce D. Gall dan M.D. Gall. 2007. Educational Research: An Introduction $8^{\text {th }}$ Edition). New York: Longman Inc

Budiyono. 2009. Statistika untuk Pendidikan Edisi Ke-2. Surakarta: Sebelas Maret University Press

Basori. 2013. Pemanfaatan Social Learning Network "Edmodo" Dalam Membantu Perkuliahan Teori Bodi Otomotif Di Prodi PTM JPTK FKIP UNS. JIPTEK, Vol. VI No.2, July 2013

Beyer, B.K. 1985. Critical Thinking: What is It? Social Education, 45

Chiu, M. M. 2008. Effects of argumentation on group micro-creativity. Contemporary Educational Psychology, 33, 383 - 402.

Chen, G., \& Chiu, M. M. 2008. Online discussion processes. Computers and Education, 50, 678 - 692 .

Chiu, M. M., \& Khoo, L. 2005. A new method for analyzing sequential processes: Dynamic multi-level analysis. Small
Development of Historical ... - Nunuk Suryani

Group Research, 36, 600-631

Darmawan, Deni. \& Permasih. 2009. Kurikulum dan Pembelajaran, Third Edition, Fourth prints. Bandung : Education Department of Curriculum and Technology Education University of Indonesia

Ministry of Education. 2003. Kurikulum 2004: Standar Kompetensi Mata Pelajaran Sejarah Jakarta: Depdiknas

Hamid, Abd. Rahman. 2014. Pembelajaran Sejarah. Yogyakarta: Ombak

Hasan, Said Hamid. 2007. "Perkembangan Kurikulum Pendidikan Sejarah di Indonesia pada Masa Kemerdekaan". Paper presented at the International Seminar on History Bandung: 6 January 2007

Haryono. 1995. Mempelajari Sejarah Secara Efektif, Jakarta: Pustaka Jaya. Ibrahim, M. \& Nur, M. 2000. Pengajaran Berdasarkan Masalah. Surabaya: UNESA-University Press.

Oakley, Lisa. 2004. Cognitive Development.London: Routledge-Taylor \& Francis Group

Prasetiono, Singgih. 2014. Pengembangan media pembelajaran e-Learning berbasis edmodo pada Kompetensi dasar menerapkan konsep dasar sistem komunikasi data Sinyal digital melalui media kabel fiber dan frekuensi radio di SMK Negeri 1 jetis mojokerto. Journal of Engineering Education 03, No. 02 Elektro.Volume 2014.151-156

Seamolec.2013. Buku sumber Simulasi Digital Versi september 2013.

Reddy, V.Venugopal and Manjulika ,S. 2002. From Face-to-Face to Virtual Tutoring: Exploring the Potentials of ELearning Support. Indira Gandhi National Open University (internet source March 2007)

Suhartini, Dewi. 2001. "Minat Siswa Terhadap Topik topik Mata Pelajaran Sejarah dan Beberapa Faktor yang Melatarbelakanginya (Studi Deskriptif Terhadap Siswa Sekolah Menengah Umum Negeri di Kota Bogor)". Unpublished Masters Thesis. Bandung: Graduate Program UPI

Supriadi, Dedi. 1994. Kreativitas, Kebudayaan dan Perkembangan IPTEK. Bandung: Alfabeta. 
Slavin. 1997. Educational Psycology Theory and Practice. Five Edition. Boston: Allin and Bacon

Suryani, Nunuk. 2009. Implementation of E - Learning in The Learning History . Paper presented at International Seminar with theme "ICT for Professional Continuous Development 2010a. Implementasi E-learning dalam Pembelajaran sejarah.Jurnal Candi. Volume 1/Tahun I/No.1/ Fenruari 2010

-----. 2010b.. Implementasi Model Pembelajara kolaboratif untuk meningkatkan Ketrampilan sosial Siswa. Majalah Ilmiah pembelajaran. Nomor 2 Volume
6 Oktober 2010 .

2011a. Model Pembelajaran Kolaboratif sebagai alternatif model pembelajaran di Perguruan Tinggi Untuk meningkatkan partisipasi aktif mahasiswa. Akademika Journal. Vol.III.no.1 Januari 2011

Vygotsky, L.S. 1978. Mind in Society: The Development of Higher Psychological Processes. Editor: Michael Cole, Vera John -Steiner, Sylvia Scribner, Ellen Souberman . Cambrigde, Massachusetts: Harvard University Press

Wiriaatmadja, Rochiati. 2002. Pendidikan Sejarah di Indonesia: Perspektif Lokal, Nasional dan Global.Bandung: Historia Utama Press. 